\title{
Social approach based on offenses, penalties and fines for animal mistreatment in Latin America
}

Planteamiento social en base a nfracciones, penas y multas por maltrato animal en América Latina

\section{Sebastián Andrés Ortega Peñafiel}

Lawyer. Lecturer at the Catholic University of Cuenca, La troncal, Ecuador

sebastian.ortega@ucacue.edu.ec

https://orcid.org/0000-0002-8477-2715

María Diana Maldonado Cabrera

Master's Degree, Teacher at the Universidad Católica de Cuenca, La troncal, Ecuador.

maria.maldonado@ucacue.edu.ec

https://orcid.org/0000-0002-6904-4541

Leiner Geanella Bejarano Paz

Student, Universidad Católica de Cuenca, La troncal, Ecuador

Victoria Elizabeth Freire Goyes

Student, Universidad Católica de Cuenca, La troncal, Ecuador

\section{Abstract}

Society suffers different types of violence, among which we find the mistreatment of domestic animals, facts that due to their nature have remained unpunished for a long time due to different aspects such as: considering animals as things lacking legal protection, the application of pecuniary sanctions and light custodial sentences for the perpetrators of different conducts ranging from abandonment to the 
death of the animal. The methodology to be used is the bibliographic review of recent publications and documents with the different legal norms of each country related to the subject. The method used is descriptive-argumentative, the collection of information starts with the use of databases, Radalyc, Proquest and Scopus. The results obtained are shown in the table of the analysis of infractions, sanctions and penalties in Latin America for animal abuse. The conclusions show that animal abuse in Latin America is one of the biggest problems facing our society, and that animals should be protected as subjects of rights, respecting their vulnerable condition. Discussion, to prevent and eradicate animal abuse it is not only enough to sanction norms, it is important to educate from home, educational centers and society.

\section{Resumen}

53 La sociedad sufre distintos tipos de violencia, entre los cuales encontramos el maltrato de animales domésticos, hechos que por su naturaleza han permanecido gran tiempo en la impunidad por diversos aspectos como son: el considerar a los animales como cosas carentes de protección jurídica, la aplicación de sanciones pecuniarias y las leves penas privativas de libertad para los autores de las distintas conductas que van desde al abandono hasta la muerte del animal. La metodología a utilizar es la revisión bibliográfica en publicaciones recientes y documental con las distintas normas jurídicas propias de cada país referentes a la temática. El método utilizado es descriptivo argumentativo, la recolección de la información parte con la utilización de base de datos, Radalyc, Proquest y Scopus. Resultados obtenidos constan en la tabla del análisis de las infracciones, sanciones y penas de América Latina por maltrato animal. Con las conclusiones se puede evidenciar que, en América Latina el maltrato animal es uno de los mayores problemas que enfrenta nuestra sociedad, se debe proteger a los animales como sujetos de derechos respetando su condición de vulnerabilidad. Discusión, para prevenir y erradicar el maltrato animal no solo basta normas sancionadoras, es importante la educación desde el hogar, centros educativos y sociedad.

\section{Palabras clave/ Keywords}

Animal abuse, Latin America, infractions, penalties, vulnerable.

Maltrato animal, América Latina, infracciones, sanciones, vulnerables. 


\section{Introduction}

The present research work on the mistreatment of pets arises from the need to provide free legal advice in all areas of law in an efficient, effective and quality manner for the defense of equality, freedom, truth and justice, as a specific objective within the Linkage Project called Free Legal Advice and Sponsorship executed by the Catholic University of Cuenca, Law School, La Troncal extension. Cifuentes \& Amariles (2017) in the development of this research, will analyze the infractions, penalties and fines in Latin America for animal abuse, violence that with the passage of time has been exercised arbitrarily despite being considered a crime in several countries, every day is increasing violent behavior, This kind of disrespect must be prevented and eradicated definitively, being the co-responsibility of the State and society, to defend the rights of those non-human living beings, but who feel pain and suffering when they are victims of violence without any possibility of defending themselves. Violence against domestic animals from the starting point of natural law exempts animals as subjects of law, this ideology has been transformed to a more iuspositivist conception that admits that beings other than humans may be subject to protection as holders of rights Garcia (2015).

Different important factors for the mistreatment of domestic animals, such as: the absence of education aimed at animal welfare should be raised with the idea of generating in society that animals should not be mistreated (Mazas \& Fernández, 2016, p.34). Impunity, lack of social transformation processes, the absence of investigations or prosecution of cases, generating uncertainty and distrust for citizens denouncing violations for the protection of animals Quiroz-Guadarrama et al., (2013) and Estrada \& Pinto (2018).

In general, animals are considered lacking in human dignity, in this explanatory line they are understood as things, but subject to legal protection. We must start from the abolition of property over animals to ensure the recognition of the normative status as subjects of law Mañalich (2018), Quiroz-Guadarrama et al. (2013) indicate that in various movements that promote animal care as the correct education of man and the whole society, promoting critical reflections on animal abuse Perez (2019). There is an authentic and multidimensional affective relationship with companion animals that is affection, both 
from humans directed to animals and from animals to humans Acero (2019).

On the other hand, the extremist current would be the elimination of the characteristic of appropriability on animals and, for this reason, endow them with autonomy of rights in relation to humans, however, this would entail industrial affectations, in legal business even in cultural practices according to Molano \& Murcia (2018) Sears et al. (2018) in Argentina establishes the ill-treatment or hiciere victim of acts of cruelty to animals. Acts of cruelty, these are repressed from imprisonment of fifteen days to one year. Brazil punishes the conduct of suppressing or altering, unduly, in the livestock or herd of others, a mark or property code sign. With a detention of six months to three years and a fine, and with imprisonment of two to five years and a fine. Bolivia punishes cruel treatment and biocide with deprivation of liberty from six months to five years. A fine of thirty to sixty days or the rendering of services of three to six months. Chile establishes acts of animal mistreatment or cruelty with a prison sentence of sixty to five hundred and forty days and a fine of two to thirty Unidades Tributarias Mensuales. Colombia typifies crimes against the life, physical and emotional integrity of animals. It is penalized with imprisonment from twelve to thirty-six months, special disqualification from one to three years for the exercise of profession, trade, office or possession related to animals and a fine of five to sixty legal monthly minimum wages in force. Cuba punishes the acts of not informing the sanitary authorities of cases of animals showing symptoms or suffering from diseases susceptible of being transmitted to other animals with a fine of three months to one year. Ecuador typifies infractions as crimes: Injury to animals that are part of the urban fauna. Sexual abuse of animals that are part of the urban fauna. Death to an animal that is part of urban fauna. Fights or combats between dogs or other animals of urban fauna. Contraventions Regulations: Abandonment of companion animals. For Panyamang et al. (2018) mistreatment of animals that are part of the scope of urban fauna. In the crimes the custodial sentences range from two days to three years and the fines are from one to ten unified basic salaries. Contraventions are punished with community work from twenty to one hundred hours without fine.

El Salvador, Guatemala, Honduras, Nicaragua, Paraguay, Puerto Rico and Venezuela classify infractions as follows: minor, serious and very serious, punishable only by fines. 


\section{Materials and Methods}

The methodology used was a bibliographic review of the different regulatory bodies established in Latin America corresponding to the mistreatment of domestic animals in the following countries: Argentina, Bolivia, Brazil, Chile, Colombia, Costa Rica, Cuba, Ecuador, El Salvador, Guatemala, Honduras, Nicaragua, Panama, Paraguay, Puerto Rico, Dominican Republic, and Venezuela.

In order to provide more value to the present research, the collection of indexed articles from international journals in the following databases was also used: Redalyc, Scopus and Proquest on current trends in animal abuse. Finally, critical discussion was used with the objective of establishing criteria on the subject to be dealt with and to establish the infractions, penalties and fines in Latin America established in the region under analysis; however, in spite of the different efforts made by the States, the weaknesses are evident and above all the increase in violence against domestic animals.

\section{Results}

After a thorough analysis of the various laws in Latin American countries, it is evident that not all of them have specific laws for the care and protection of animals, however, they are covered by criminal law as crimes of public and private practice and within administrative law.

Based on what has been analyzed in the Latin American regulations regarding the mistreatment of domestic animals, we deduce that although there are regulations established with the purpose of recognizing animals' rights as living beings, thus leaving aside the erroneous ideology that animals are not things devoid of feelings and sensations, recognizing them as beings deserving of protection.

There is a minimum valuation towards the life of pets, since the penalties imposed are generally light compared to those imposed for other acts that do not involve taking a life, we should remember that all lives matter and even more so when the one who is being taken away is a being in a state of defenselessness.

After analyzing country by country in Latin America, it can be seen that they have protective regulations in favor of domestic animals, it was identified that the typification varies in the criminal field as crimes and misdemeanors, in the administrative field are established as minor, 
serious and very serious infractions, their penalties range from a warning, fine to imprisonment. Now, to prevent and eradicate violence against domestic animals, not only laws are needed, the problem lies in the culture and education of each country to consider animals as sentient beings, not as replaceable things. On the other hand, reforms such as in Ecuador show greater punishments to people who commit any act against animal rights.

\section{Conclusions}

In Latin America, animal abuse is one of the major problems facing our society. Several countries in the Region are trying in one way or another to prevent, eradicate and, above all, punish behaviors that violate the rights of domestic animals, as an example, the regulatory bodies investigated establish different administrative and criminal offenses, the former constituting minor, serious and very serious offenses and the latter typified as public and private offenses and contraventions.

Since animal abuse is an element that predisposes to social violence, the State and society must work together to eradicate animal abuse because when it is intentionally exercised by mentally unstable people it constitutes a threat to both non-humans and humans, and we must not be indifferent to the violation of the rights of defenseless beings who are under our guardianship and care. Finally, we conclude by affirming that the importance of the establishment and above all compliance by all members of a nation of laws that protect those who are part of this vulnerable group lies in the fact that the way in which animals are treated by a State speaks of the moral progress that it has constituted as humanity; respect for life in all its forms is synonymous with greatness.

\section{References}

Steel, M. (2019). That very special relationship with dogs and with cats: the multispecies family and its metaphors. Tabula Rasa, 32(4) 157-179. Retrieved from https://www.redalyc.org/articulo.oa?id=396/39661317008.

Cifuentes, L., \& Amariles, P. (2017). Takotsubo cardiomyopathy triggered by the use or exposure to drugs of abuse, chemical substances or poisons of animal origin. Revista Colombiana de Cardiologia, 24(2), 117-127. 
https://doi.org/10.1016/j.rccar.2016.05.015.

Estrada, G. E., \& Pinto, D. F.. (2018). Study of the Colombian regulatory framework for equines as blood-drawn vehicles. Science and Agriculture, 45(4)69-80. https://www.redalyc.org/articulo.oa?id=5600/56006346500 8.

García, M. (2015). The crime of animal abuse. The legislative mistreatment to their protection. Journal of Bioethics and Law, 34 https://www.redalyc.org/articulo.oa?id=783/78343122008.

Mañalich, J. (2018). Animality and subjectivity. (Non-human) animals as subjects-of-law. Law Review. Vol. 41(3), 335-345. http://dx.doi.org/10.4067/So718-09502018000200321

Mazas, B., \& Fernández, R. (2016). The concept of animal welfare in the Compulsory Secondary School curriculum and in science textbooks. Eureka Journal on Science Education and Outreach. $\quad$ 45(5) 13-20 .//www.redalyc.org/articulo.oa?id=920/92044744006.

Molano Bustacara, Alejandra, \& Murcia Riaño, Diana (2018). Animals and nature as new subjects of law: a study of the most relevant judicial decisions in Colombia. Colombian Journal of Bioethics, 13(1),82-103.

https://www.redalyc.org/articulo.oa?id=189257376004

Panyamang, A., Duangpakdee, O., \& Rattanawannee, A. (2018). Genetic structure of teak beehole borer, Xyleutes ceramicus (Lepidoptera: Cossidae), in northern Thailand. Agriculture and Natural Resources, 52(1), 66-74. https://doi.org/10.1016/j.anres.2018.05.008.

Pérez, J. J. (2019). Contractualism as a foundation of implication in moral questions about nature and the environment.evista Colombiana de Bioética, 30(4) 69-82.

Quiroz-Guadarrama, C. D., Rojano-Rodriguez, M., Herrera-Esquivel, J. J., De La Concha-Bermejillo, F., Romero-Loera, L. S., Estrada-Moscoso, I., Del Rio-Suarez, I., Morales-Vargas, J. M., Torres-Ruiz, M. F., Gonzalez-Angulo, J. A., BeristainHernandez, J. L., Alonso-Lárraga, J., Cárdenas-Lailson, E., \& 
Moreno-Portillo, M. (2013). Full- and partial-thickness oral endoscopic myotomy. Feasibility study in an animal model. Revista de Gastroenterologia de Mexico, 78(4), 225-230. https://doi.org/10.1016/j.rgmx.2013.08.002.

Sears, R. R., Cronkleton, P., Polo Villanueva, F., Miranda Ruiz, M., \& Pérez-Ojeda del Arco, M. (2018). Farm-forestry in the Peruvian Amazon and the feasibility of its regulation through forest policy reform. Forest Policy and Economics, 87(November 2017), 49-58. https://doi.org/10.1016/j.forpol.2017.11.004. 